\title{
Aphis pomi and Aphis spiraecola (Hemiptera: Sternorrhyncha: Aphididae) in Europe - new information on their distribution, molecular and morphological peculiarities
}

\author{
RIMANTAS RAKAUSKAS, JEKATERINA BAŠILOVA and RASA BERNOTIENE்
}

Department of Zoology, Faculty of Natural Sciences, Vilnius University, Čiurlionio str. 21/27, LT 03101 Vilnius, Lithuania; e-mails: rimantas.rakauskas@gf.vu.lt; jekaterina.basilova@gf.vu.lt; rasa.bernotiene@gf.vu.lt

\begin{abstract}
Key words. Hemiptera, Aphididae, Aphis pomi, Aphis spiraecola, apple aphid, spirea aphid, morphometrics, identification,
\end{abstract} mitochondrial COI, nuclear EF-1 $\alpha$

\begin{abstract}
Aphid species Aphis pomi (de Geer, 1773) is oligophagous on pomoideous host plants, whilst Aphis spiraecola Patch, 1914 is a polyphagous species alternating between Spiraea spp., its primary host, and a wide variety of secondary hosts, also including pomoideous species. Despite the biological distinction, these species are difficult to separate using their morphological characters. Partial sequences of mitochondrial COI and nuclear EF-1 $\alpha$ genes were analyzed for samples from Central and Eastern Europe, Germany, Bulgaria, Italy, Turkey, China together with available data from GenBank. Interspecific pairwise sample divergences of the COI fragment ranged from 3.1 to $4.3 \%$. One COI haplotype of $A$. pomi was predominant $(\mathrm{n}=24)$, with a pan European distribution. The most abundant COI haplotype of $A$. spiraecola $(\mathrm{n}=16)$ occurred in Lithuania, Latvia, Poland, Italy, Turkey and China. Interspecific pairwise sample divergences of the EF-1 $\alpha$ fragment ranged from 0.6 to $1.2 \%$. Analyzed partial sequences of EF-1 $\alpha$ were identical in $A$. pomi. The most abundant EF-1 $\alpha$ haplotype of $A$. spiraecola $(\mathrm{n}=14)$ occurred in Lithuania, Poland, Italy, Turkey and China. The length of ultimate rostral segment appeared to be the most reliable morphological character for discrimination between apple and spirea aphid species. It allowed a $100 \%$ correct identification of $A$. pomi $(\mathrm{n}=143)$ and $91.5 \%$ of $A$. spiraecola $(\mathrm{n}=94)$ specimens in the European samples used for the molecular analysis. The existence of $A$. spiraecola in the Eastern Baltic region of Europe is documented for the first time.
\end{abstract}

\section{INTRODUCTION}

Aphis pomi (de Geer, 1773) (apple aphid) and Aphis spiraecola Patch, 1914 (spirea aphid) are reported to be serious pests of horticulture all over the World (Blackman \& Eastop, 2000; Holman, 2009). Their distribution, morphology, life cycles and host specificity have therefore been subjected to intensive study, together with their potential harmfulness and plant protection measures (Grasswitz \& Burts, 1995; Tsai \& Wang, 2001; Brown et al., 2008; Stoeckli et al., 2008; Frechette et al., 2008; Brown, 2011; Wieczorek et al., 2011; Cao et al., 2012). The apple aphid is monoecious and holocyclic on woody pomoideous hosts, with apterous males (Baker \& Turner, 1916; Patch, 1923; Westigard \& Madsen, 1964; Karczewska, 1965; Rakauskas \& Rupais, 1983). The spirea aphid is holocyclic and heteroecious in North America, Brazil and Japan, with Spiraea species as its primary host and a wide variety of secondary hosts belonging to more than 20 families, including many of those of the apple aphid; anholocyclic lineages of spirea aphid occur worldwide (Patch, 1929; Komazaki, 1990; Kaakeh et al., 1993; Blackman \& Eastop, 2000; Holman, 2009). Unlike the males of the apple aphid, those of the spirea aphid are winged and the oviparae have swollen tibiae (Palmer, 1952; Halbert \& Voegtlin, 1992). Despite suggested morphology-based discrimination characters (Stroyan, 1985; Heie, 1986; Halbert \& Voegtlin, 1992; Blackman \& Eastop, 2000; Foottit et al., 2009), close morphological similarity of winged and apterous viviparous females together with overlapping of host plant lists has caused confusion over the identity of both species (Singh \& Rhomberg, 1984; Stroyan, 1985; Heie, 1986; Halbert \& Voegtlin, 1992; Blackman \& Eastop, 2000). Namely, authors reporting winged males of the apple aphid (Davletshina, 1963; Karczewska, 1965) might actually refer to the spirea aphid. Competitive displacement of apple aphid by spirea aphid is reported as mediated by human activities in North America (Hogmire et al., 1992; Brown et al., 1995; Lowery et al., 2006; Smirle et al., 2010), making host plant based discrimination of both species even more complicated. Recently, a resolution of this discrimination problem was proposed using molecular taxonomy (Lushai et al., 2004; Foottit et al., 2009; Naaum et al., 2012).

In Europe, apple aphid is a common species, whilst spirea aphid is currently reported mostly from southern Europe, reaching British Isles, Germany and Ukraine in the north (Holman, 2009; Nieto Nafria et al., 2010). Yet morphology-based identification make some records uncertain (Jaskiewicz \& Kot, 2007; Caglayan et al., 2013; Yovkova et al., 2013). Spirea aphid is reported to be the principle pest on citrus, occasionally also on Prunoidea (stone fruits), but not apple or other pomoideae in Europe (Barbagallo et al., 1997).

Recently, the spirea aphid was reported from a more northernly part of Europe, in Poland, on Kalanchoe blossfeldiana, Polyscias fabiana, Schefflera arboricola in a greenhouse (Labanowski, 2008) and in Belarus, on Spi- 
raea alba outdoors (Rakauskas \& Buga, 2010). A. spiraecola-like aphids were collected from Spiraea sp. outdoors also in Latvia (2008) and Lithuania (2005, 2012-2014) (R. Rakauskas, unpubl.). The aim of this study is to identify the available European samples of the $A$. pomi-spiraecola species complex using partial sequences of mitochondrial $\mathrm{COI}$ and nuclear EF-1 $\alpha$ genes and test the reliability of the morphological characters used to discriminate between these two species (Blackman \& Eastop, 2000; Foottit et al., 2009).

\section{MATERIAL AND METHODS}

\section{Samples}

Aphid material collected in 2004-2013 included forty nine samples from ten European countries, Turkey and China (Table 1). Microscope slides in Canada balsam were prepared according to Blackman \& Eastop (2000). Ethanol-preserved and mounted specimens are stored at the Department of Zoology, Vilnius University.

\section{DNA extraction, fragment amplification and sequencing}

For molecular analysis, a single aphid from one plant was considered as a unique sample. Total genomic DNA was extracted from each aphid using the DNeasy Blood \& Tissue kit (Qiagen), which involved at least a $2 \mathrm{~h}$ digestion of tissue with proteinase K. For the amplification of mitochondrial COI and nuclear EF-1 $\alpha$ gene fragments previously published primers, AphisL-465/Aphis-H-1068 and Eloaphis-F/Eloaphis-R (Turčinavičienè et al., 2006), were used. PCR amplification was carried out in a thermal cycler (Eppendorf) in $50 \mu \mathrm{l}$ volumes containing 2 $\mu 1$ genomic DNA, $5 \mu 1$ of each primer $(10 \mu \mathrm{M}), 5 \mu 1$ of PCRreaction buffer, $5 \mu \mathrm{l}$ of dNTP mix (2mM each), $4-8 \mu 1$ of $25 \mathrm{mM}$ $\mathrm{MgCl}_{2}$ and $1.25 \mathrm{U}$ of AmpliTaq Gold 360 polymerase $(5 \mathrm{U} / \mu \mathrm{l})$ and $\mathrm{ddH}_{2} \mathrm{O}$ to $50 \mu \mathrm{l}$. The cycling parameters were as follows: denaturizing at $95^{\circ} \mathrm{C}$ for $10 \mathrm{~min}$, denaturizing at $95^{\circ} \mathrm{C}$ for $30^{\prime \prime}$, annealing at $49^{\circ} \mathrm{C}$ (for $\mathrm{COI}$ ) or $57^{\circ} \mathrm{C}$ (for EF-1 $\alpha$ ) for 30 " and extension at $72^{\circ} \mathrm{C}$ for $30^{\prime \prime}(32-37$ cycles in total), and a final extension for 5 $\min$.

PCR products were purified and sequenced at the Institute of Biotechnology, Vilnius University (Vilnius, Lithuania). The amplification primers were also used as sequencing primers. DNA sequences for each specimen were confirmed with both sense and anti-sense strands and aligned in the BioEdit Sequence Alignment Editor (Hall, 1999). Partial COI sequences were tested for stop codons and none were found. The sequence data have been submitted to GenBank, Accession numbers are given in Table 1.

\section{DNA sequence data analysis}

In addition, available partial sequences of mitochondrial COI ( 1 of $A$. pomi and 11 of $A$. spiraecola) and nuclear EF-1 $\alpha$ ( 7 of A. spiraecola) were downloaded from GenBank (Table 2). To avoid any discrepancies when analyzing data, sequences of both fragments were aligned and those matching partial sequences obtained from samples collected during this study were selected for further procedures. For sequences from GenBank geographic origin of samples and their host plants were obtained from publications (Table 2).

Phylogenetic analyses with a sequence of Nasonovia ribisnigri (Mosley, 1841) (tribe Macrosiphini, family Aphididae) as outgroup species, included Neighbour joining (NJ), Maximum parsimony (MP), Maximum likelihood (ML) and Bayesian inference in phylogeny (BI). NJ, MP and ML analyses were performed using MEGA 5 (Tamura et al., 2011). For NJ and distance analyses Kimura 2-parameter (K2P) model of base substitution was used. ML analysis was performed using Tamura 3-parameter model with invariable sites $(\mathrm{T} 92+\mathrm{I})$ for COI and Tamura 3-parameter model (T92) for EF-1 $\alpha$, which were selected by MEGA 5 model selection option (Tamura et al., 2011). Bootstrap values for NJ, MP and ML trees were generated from 1000 replicates. Bayesian analysis was conducted in MrBayes 3.2.1 (Ronquist \& Huelsenbeck, 2003) using Hasegawa-Kishino-Yano model with Invariable sites $(\mathrm{HKY}+\mathrm{I})$ for $\mathrm{COI}$ and Felsenstein model with Invariable sites and Gamma distribution $(\mathrm{F} 81+\mathrm{I}+\mathrm{G})$ for $\mathrm{EF}-1 \alpha$, which were selected by jModeltest (Posada, 2008). One run for $1,000,000$ generations with tree sampling every 1,000 generations was performed using the uniform model of the molecular clock.

Statistical parsimony networks with $95 \%$ implemented connection limit were constructed using TCS v 1.21 (Clement et al., 2000). For analysis of partial COI sequences gaps were treated as missing data, while EF-1 $\alpha$ fragment gaps were treated as a 5th state.

\section{Morphometrics}

Samples representing different clades in the molecular tree and haplotype network were used to verify the characters commonly used in the morphology-based keys discriminating both species (Halbert \& Voegtlin, 1992; Blackman \& Eastop, 2000; Foottit et al., 2009). The following characters were selected: URS - ultimate rostral segment length; SIPHON - siphunculus length; CAUDA - length of cauda (apical part); MT2-4(5) - numbers of marginal tubercles on abdominal tergites II-IV(V); HCAUDA - numbers of caudal hairs; SIPHON/CAUDA - ratio of siphuncular length to caudal (apical part) length. Measurements of slide-mounted apterous viviparous females were made using the interactive measurement system Micro-Image (Olympus Optical Co. $\mathrm{GmbH})$.

\section{RESULTS}

The alignment of COI fragment contained 621 sites, of which 68 were variable and 26 parsimony informative. Average nucleotide composition was $\mathrm{T}-37.7 \%, \mathrm{C}-14.6 \%$, $\mathrm{A}-35.2 \%, \mathrm{G}-12.5 \%$. The overall transition/transversion bias was $\mathrm{R}=3.075$. The range in the intraspecific pairwise sample divergences (K2P model) was $0.0-0.8 \%$ (average $0.1 \%$ ) for $A$. pomi and $0.0-0.5 \%$ (average $0.2 \%$ ) for $A$. spiraecola. Interspecific pairwise sample divergences between these two species ranged from 3.1 to $4.3 \%$ (average $3.6 \%)$.

After the construction of networks based on statistical parsimony (Fig. 1) 31 partial COI sequences of $A$. pomi and 30 sequences of $A$. spiraecola were collapsed into seven haplotypes each. The number of COI haplotypes, sequence length and sample or sequence numbers are given in Table 3; details for each sample (country, host plant and collection date) are given in Tables 1-2.

Most of the A. pomi samples $(\mathrm{n}=24)$ had the same COI haplotype (No. 1) and were collected in Latvia $(\mathrm{n}=7)$, Lithuania $(n=5)$, Poland $(n=4)$, Estonia $(n=2)$, Czech Republic $(\mathrm{n}=2)$, Belarus $(\mathrm{n}=1)$, Ukraine $(\mathrm{n}=1)$, Bulgaria $(\mathrm{n}=1)$ and Germany $(\mathrm{n}=1)$. This haplotype seems to be the most common in Europe. COI haplotype No. 5 was detected only in samples from Lithuania $(\mathrm{n}=1)$ and Latvia ( $\mathrm{n}$ $=1$ ). Remaining 5 haplotypes were represented by single samples from Estonia, Ukraine, Czech Republic and China (Tables 1-3, Fig. 1). 
TABLE 1. Samples of Aphis pomi and Aphis spiraecola examined in this study. COI - Mitochondrial cytochrome oxidase subunit I, EF-1 $\alpha$ - nuclear elongation factor 1 alpha.

\begin{tabular}{|c|c|c|}
\hline \multicolumn{2}{|c|}{ GenBank accession No. } & \multirow{2}{*}{ Sample information and No. } \\
\hline COI & EF-1 $1 \alpha$ & \\
\hline \multicolumn{3}{|r|}{ Aphis pomi } \\
\hline KM017584 & KM017457 & Štramberk, North Moravia, Czech Rep., 2005.vi.15, Cotoneaster sp., 05-22 \\
\hline KM017583 & KM017458 & České Budějovice, South Bohemia, Czech Rep., 2005.vi.17, Crataegus sp. 05-34 \\
\hline KM017589 & KM017459 & České Budějovice, South Bohemia, Czech Rep., 2005.vi.17, Spiraea sp. 05-35 \\
\hline KM017591 & KM017460 & České Budějovice, South Bohemia, Czech Rep., 2005.vi.18, Malus domestica, 05-42 \\
\hline KM017582 & KM017461 & Skirgiškès, Vilnius distr., Lithuania, 2005.vii.12, Cotoneaster sp., 05-68 \\
\hline KM017579 & KM017462 & Kyiv, Ukraine, 2006.vi.12, Spiraea salicifolia, 06-32 \\
\hline KM017590 & KM017463 & Kyiv, Ukraine, 2006.vi.13, Crataegus sp., 06-43 \\
\hline KM017580 & KM017464 & Zadrachje, Gorodok distr., Belarus, 2008.vi.18, Malus domestica, 08-23 \\
\hline KM017581 & KM017465 & Riga, Latvia, 2008.vii.03, Malus domestica, 08-72 \\
\hline KM017592 & KM017466 & Salaspils, Latvia, 2008.vii.04, Aronia melanocarpa, 08-91 \\
\hline KM017577 & KM017467 & Lublin, Poland, 2008.ix.01, Malus domestica, 08-112 \\
\hline KM017578 & KM017468 & Lublin, Poland, 2008.ix.02, Crataegus sp., 08-117 \\
\hline KM033438 & KM017469 & Przewiez, Podlasie, Poland, 2009.ix.29, Malus sp. cult., 09-45 \\
\hline KM017567 & KM017470 & Blagojevgrad, Bulgaria, 2012.vi.26, Malus sp., 12-87 \\
\hline KM017568 & KM017471 & Frankfurt/Maine, Germany, 2012.vi.30, Malus domestica, 12-105 \\
\hline KM017593 & KM017472 & Kraujaliai, Molètai distr., Lithuania, 2012.vii.10, Pyrus sp., 12-112 \\
\hline KM017569 & KM017473 & Kraujaliai, Molètai distr., Lithuania, 2012.vii.10, Malus domestica, 12-115 \\
\hline KM017570 & KM017474 & Stirniai, Molètai distr., Lithuania, 2012.vii.12, Cotoneaster sp., 12-125 \\
\hline KM017571 & KM017475 & Vidugiris, Molètai distr., Lithuania, 2012.vii.13, Sorbus aucuparia, 12-133 \\
\hline KM017572 & KM017476 & Kegums, Latvia, 2012.vii.30, Pyrus communis, 12-144 \\
\hline KM017573 & KM017477 & Kegums, Latvia, 2012.vii.30, Malus domestica, 12-145 \\
\hline KM017574 & KM017478 & Skriveri, Latvia, 2012.viii.01, Crataegus sp., 12-152 \\
\hline KM017575 & KM017479 & Sangaste, Valga county, Estonia, 2012.viii.01, Malus domestica, 12-159 \\
\hline KM033439 & KM017480 & Tartu, Estonia, 2012.viii.03, Cotoneaster sp., 12-160 \\
\hline KM017588 & KM017481 & Tartu, Estonia, 2012.viii.03, Crataegus sp., 12-161 \\
\hline KM017576 & KM017482 & Juodkrantè, Neringa, Lithuania, 2012.viii.10, Crataegus sp., 12-183 \\
\hline KM017585 & KM017483 & Wojslawice, Lower Silesia, Poland, 2013.vi.20, Amelanchier lamarckii, 13-100 \\
\hline KM033441 & KM017484 & Rundale, Latvia, 2013.vii.02, Cydonia sp., 13-106 \\
\hline KM017586 & KM017485 & Rēzekne, Latvia, 2013.vii.16, Cotoneaster sp., 13-127 \\
\hline KM017587 & KM017486 & Karsava, Latvia, 2013.vii.17, Cotoneaster sp., 13-134 \\
\hline \multicolumn{3}{|r|}{ Aphis spiraecola } \\
\hline KM017600 & KM017487 & Catania, Sicily, Italy, 2004.vi.26, Pittosporum sp., 04-39 \\
\hline KM017599 & KM017488 & Skirgiškès, Vilnius distr., Lithuania, 2005.vii.12, Spiraea sp., 05-70 \\
\hline KM017595 & KM017489 & Salaspils, Latvia, 2008.vii.04, Spiraea sp., 08-78 \\
\hline KM017597 & KM017490 & Sigulda, Latvia, 2008.vii.06, Spiraea sp., 08-97 \\
\hline KM017596 & KM017492 & Lublin, Poland, 2008.ix.02, Cotoneaster sp., 08-115 \\
\hline KM017610 & KM017491 & Randazzo, Sicily, Italy, 2009.vi.10, Cotoneaster sp., 09-18 \\
\hline KM017611 & KM017493 & Karamanmarash, Turkey, 2011.v.28, Spiraea sp., 11-16 \\
\hline KM017598 & KM017494 & Karamanmarash, Turkey, 2011.v.28, Armeniaca vulgaris, 11-17 \\
\hline KM017594 & KM017495 & Šalčininkai, Lithuania, 2012.vi.13, Spiraea sp., 12-52 \\
\hline KM017609 & KM017496 & Preila, Neringa, Lithuania, 2012.viii.13, Prunus cerasifera, 12-200 \\
\hline KM017601 & KM017497 & Bagnolo Mella, Brescia prov., Italy, 2013.iv.28, Chaenomeles sp., 13-17 \\
\hline KM017602 & KM017498 & Poncarale, Brescia prov., Italy, 2013.v.02, Chaenomeles sp., 13-34 \\
\hline KM017604 & KM017499 & Beijing, China, 2013.vi.03, Malus sp., 13-68 \\
\hline KM017605 & KM017500 & Muntianyu, Huairou county, China, 2013.vi.04, Malus sp., 13-69 \\
\hline KM017606 & KM017501 & Beijing, China, 2013.vi.06, Chaenomeles sp., 13-71 \\
\hline KM017607 & KM017502 & Beijing, China, 2013.vi.06, Prunus cerasifera Pissardii, 13-72 \\
\hline KM017608 & KM017503 & Beijing, China, 2013.vi.03, Malus sp., 13-74 \\
\hline KM033440 & KM017504 & Pawłowice, Lower Silesia, Poland, 2013.vi.21, Prunus cerasifera, 13-101 \\
\hline KM017603 & KM017505 & Pawłowice, Lower Silesia, Poland, 2013.vi.21, Prunus mahaleb, 13-102 \\
\hline
\end{tabular}




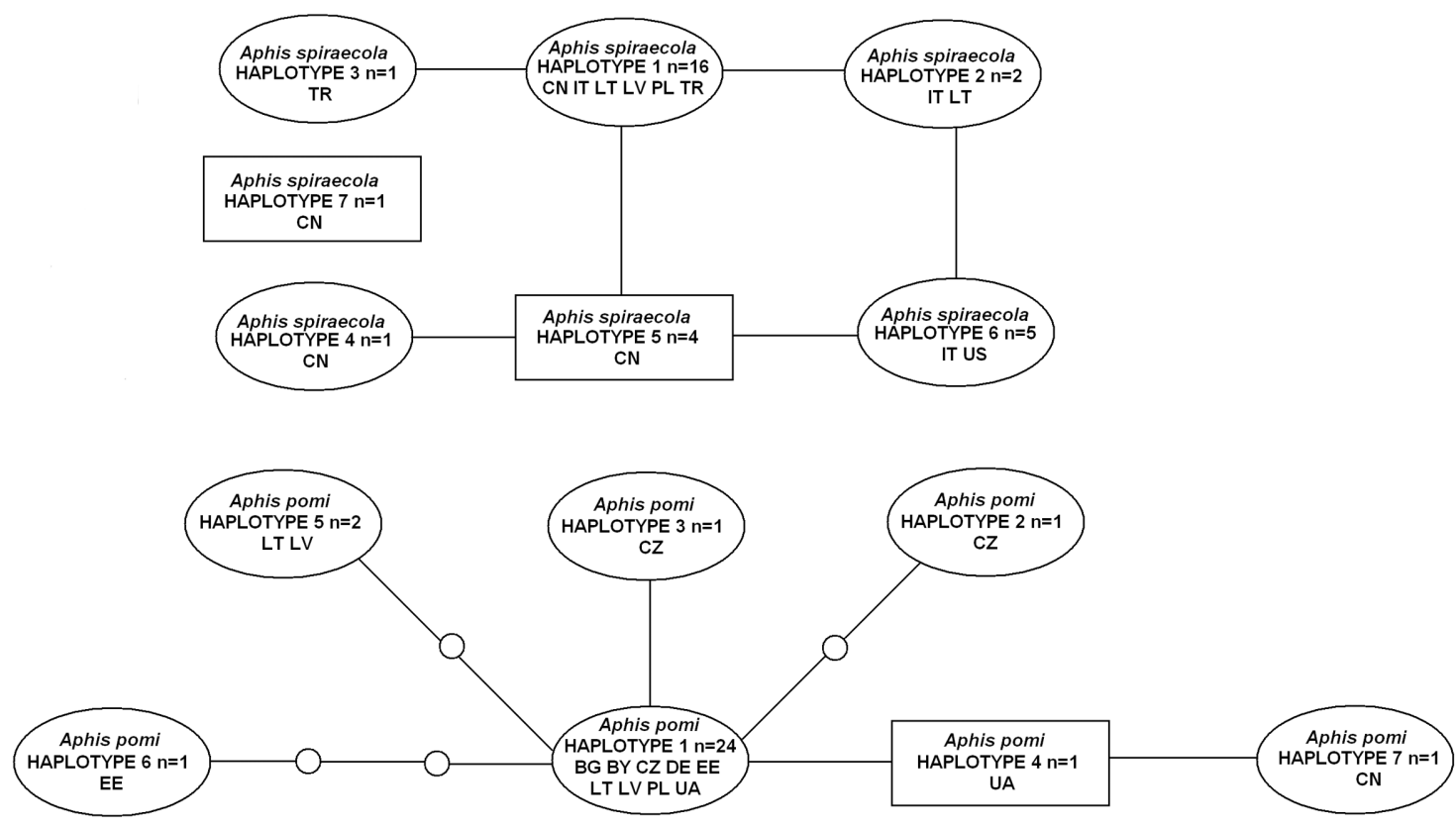

Fig. 1. Haplotype networks for COI fragment (621 positions in final set, 95\% connection limit, gaps treated as missing data) haplotypes of $A$. pomi and A. spiraecola. The haplotype with the highest outgroup probability is displayed as a square, while others are displayed as ovals. For sample information, see Tables 1-3. BG - Bulgaria, BY - Belarus, CN - China, CZ - Czech Republic, DE - Germany, EE - Estonia, IT - Italy, LV - Latvia, LT - Lithuania, PL - Poland, TR - Turkey, UA - Ukraine, US - United States of America.

The most common COI haplotype of A. spiraecola (No. $1, \mathrm{n}=16)$ occurred in samples from China $(\mathrm{n}=5)$, Italy $(\mathrm{n}=3)$, Poland $(\mathrm{n}=3)$, Latvia $(\mathrm{n}=2)$, Lithuania $(\mathrm{n}=2)$ and Turkey $(\mathrm{n}=1)$. (Tables $1-3$, Fig. 1). Haplotype No. 6 $(\mathrm{n}=5)$ was collected in Italy $(\mathrm{n}=3)$ and USA $(\mathrm{n}=2)$ and haplotype No. $5(\mathrm{n}=4)$ only in China. Haplotype No. 2 $(\mathrm{n}=2)$ was collected in Italy and Lithuania. Unique COI haplotypes represented by a single sequence were detected in material collected in Turkey (No. 3) and China (No. 4). Our data do not indicate any clear geographical back- ground in the distribution of the COI haplotypes of apple and spirea aphids analyzed.

Out of 31 partial COI sequences of $A$. pomi, host plant information was available for 30 of them (Tables 1-2). The most abundant COI haplotype No. $1(\mathrm{n}=24)$ occurred in samples collected from Malus, Pyrus, Cotoneaster, Crataegus, Spiraea, Sorbus, Cydonia and Amelanchier, and is clearly not host specific. Unique COI haplotypes were also not host specific as they were collected from the same hosts (Malus, Spiraea and Crataegus) as the most common

TABLE 2. Partial sequences of COI and EF-1 $\alpha$ from GenBank that were used in the present study for comparison.

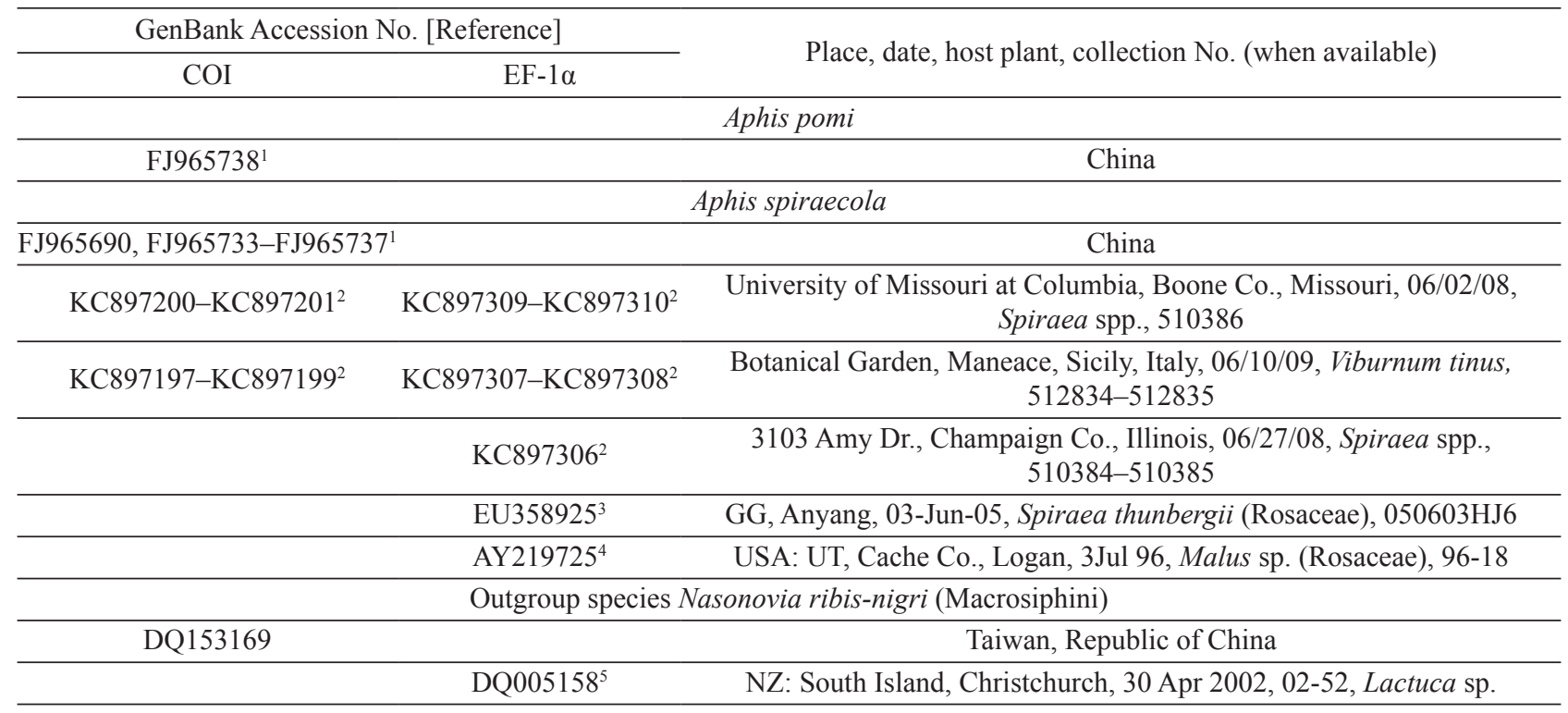

${ }^{1}$ Wang et al., 2011; ${ }^{2}$ Lagos et al., 2014; ${ }^{3}$ Kim \& Lee, 2008; ${ }^{4}$ von Dohlen \& Teulon, 2003; ${ }^{5}$ von Dohlen et al., 2006. 
TABLE 3. COI haplotypes of Aphis pomi and Aphis spiraecola revealed by the haplotype network analysis. Sample numbers are the same as in Tables $1-2$.

\begin{tabular}{|c|c|c|c|}
\hline $\begin{array}{l}\text { Haplotype } \\
\text { no. }\end{array}$ & $\begin{array}{c}\text { No. of } \\
\text { sequences }\end{array}$ & $\begin{array}{l}\text { Length of haplotype } \\
\text { (bp) without gaps }\end{array}$ & Sequences belonging to haplotype \\
\hline \multicolumn{4}{|r|}{ Aphis pomi } \\
\hline 1 & 24 & 621 & $\begin{array}{c}05-22 ; 05-34 ; 05-68 ; 06-32 ; 08-23 ; 08-72 ; 08-112 ; 08-117 ; 09-45 ; 12-87 ; 12-105 ; 12- \\
115 ; 12-125 ; 12-133 ; 12-144 ; 12-145 ; 12-152 ; 12-159 ; 12-160 ; 12-183 ; 13-100 ; 13-106 ; \\
13-127 ; 13-134\end{array}$ \\
\hline 2 & 1 & 621 & $05-35$ \\
\hline 3 & 1 & 621 & $05-42$ \\
\hline 4 & 1 & 621 & $06-43$ \\
\hline 5 & 2 & 621 & $08-91 ; 12-112$ \\
\hline 6 & 1 & 621 & $12-161$ \\
\hline 7 & 1 & 621 & FJ965738 \\
\hline \multicolumn{4}{|r|}{ Aphis spiraecola } \\
\hline 1 & 16 & 621 & $\begin{array}{c}04-39 ; 05-70 ; 08-78 ; 08-97 ; 08-115 ; 11-17 ; 12-52 ; 13-17 ; 13-34 ; 13-68 ; 13-69 ; 13-71 \\
13-72 ; 13-74 ; 13-101 ; 13-102\end{array}$ \\
\hline 2 & 2 & 621 & $09-18 ; 12-200$ \\
\hline 3 & 1 & 621 & $11-16$ \\
\hline 4 & 1 & 621 & FJ965737 \\
\hline 5 & 4 & 621 & FJ965736; FJ965735; FJ965734; FJ965733 \\
\hline 6 & 5 & 621 & KC897201; KC897200; KC897199; KC897198; KC897197 \\
\hline 7 & 1 & 621 & FJ965690 \\
\hline
\end{tabular}

haplotype. This is also the case for the rare haplotype No. 5, which was recorded in samples from Aronia and Pyrus.

Of the 30 partial COI sequences of spirea aphid there is host plant information for 24 . As in case of the apple aphid, the most common haplotype of spirea aphid appeared to be polyphagous, as it was collected from a broad spectrum of hosts, including those of the apple aphid: Spiraea $(\mathrm{n}=$ 4), Chaenomeles $(\mathrm{n}=3)$, Prunus $(\mathrm{n}=3)$, Malus $(\mathrm{n}=3)$, Cotoneaster $(\mathrm{n}=1)$, Pittosporum $(\mathrm{n}=1)$ and Armeniaca $(\mathrm{n}=1)$. Remaining haplotypes of spirea aphid shared the same hosts with the commonest haplotype, except three samples of haplotype No. 6, collected from Viburnum in Italy (Sicily).

The maximum parsimony (MP) analysis of partial COI sequences resulted in 618 equally parsimonious trees (length $=105, \mathrm{CI}=0.79, \mathrm{RI}=0.98) . \mathrm{ML}$ tree $(\mathrm{T} 92+\mathrm{I} \bmod -$ el) had a similar topology to the NJ (K2P distances) and BI (HKY+I model) analyses. NJ, MP and ML bootstrap values over $40 \%$ together with $\mathrm{BI}$ posterior probabilities over 0.50 are given at the respective nodes of the same tree in Fig. 2. The two Aphis species form distinct strongly supported clusters. The apple aphid clade is highly homogenous. Only four specimens from Lithuania, Latvia, Ukraine and China do not group with the remaining samples (Fig. 2). The clade of the spirea aphid appears more complex, comprising four moderately supported branches, one of them being represented only by Chinese samples $(\mathrm{n}=5)$. Noticeably, GenBank sequence No. FJ965690 from China deposited as A. spiraecola, grouped outside the spirea aphid clade, both in the haplotype network (Fig. 1) and phylogenetic tree (Fig. 2). It appeared closer to the outgroup sequence of Nasonovia ribis-nigri, belonging to the tribe Macrosiphini of the aphid subfamily Aphidinae (Aphididae). This indicates an incorrect identification of the sequenced aphid specimen, because the genus Aphis belongs to the tribe Aphidini.

The analyzed region of EF-1 $\alpha$ consisted of two parts of three exons and two introns, which were not removed before further analysis. The alignment of this fragment contained 510 sites, 6 of which were variable and parsimony informative. The average nucleotide composition was: $\mathrm{T}$ $-30.3 \%, \mathrm{C}-18.2 \%, \mathrm{~A}-31.4 \%$ and $\mathrm{G}-20.1 \%$. The overall transition/transversion bias was $\mathrm{R}=1.335$. Interspecific pairwise sample divergences between spirea and apple aphid species ranged from 0.6 to $1.2 \%$ (average $0.9 \%$ ). The range of the intraspecific pairwise sample divergences (K2P model) for the spirea aphid was $0-0.6 \%$ (average $0.2 \%$ ), whilst all sequences of the apple aphid appeared identical. Noticeably, EF-1 $\alpha$ sequences of the apple aphid differed from the closest haplotype of the spirea aphid in terms of only three base changes (Fig. 3), which is usually the characteristic of closely related haplotypes, attributable to the same species in the haplotype network.

All partial EF-1 $\alpha$ sequences of the apple aphid $(n=30)$ from 9 European countries were identical, thus, no correlation between haplotypes and geographic origin could be detected. Five haplotypes were identified among the 26 partial EF-1 $\alpha$ sequences of spirea aphid, (Tables 1, 2, 4, Fig. 3). Most of the samples ( $n=14$ altogether) from China $(\mathrm{n}=5)$, Italy $(\mathrm{n}=4)$, Poland $(\mathrm{n}=2)$, Lithuania $(\mathrm{n}$ $=1)$ and Turkey $(\mathrm{n}=2)$ included EF-1 $\alpha$ haplotype No. 1 . EF-1 $\alpha$ haplotype No. $2(n=5)$ was recorded in samples from Lithuania $(\mathrm{n}=2)$, Latvia $(\mathrm{n}=2)$ and Poland $(\mathrm{n}=1)$, and EF-1 $\alpha$ haplotype No. 3 in samples from Italy $(n=3)$ and USA $(\mathrm{n}=2)$. There is one more haplotype (No. 5, $\mathrm{n}=$ 1) reported in the USA. Haplotype (No. 4) was represented by single sequence from Korea. As for the COI haplotypes, our data do not indicate any geographical background in 


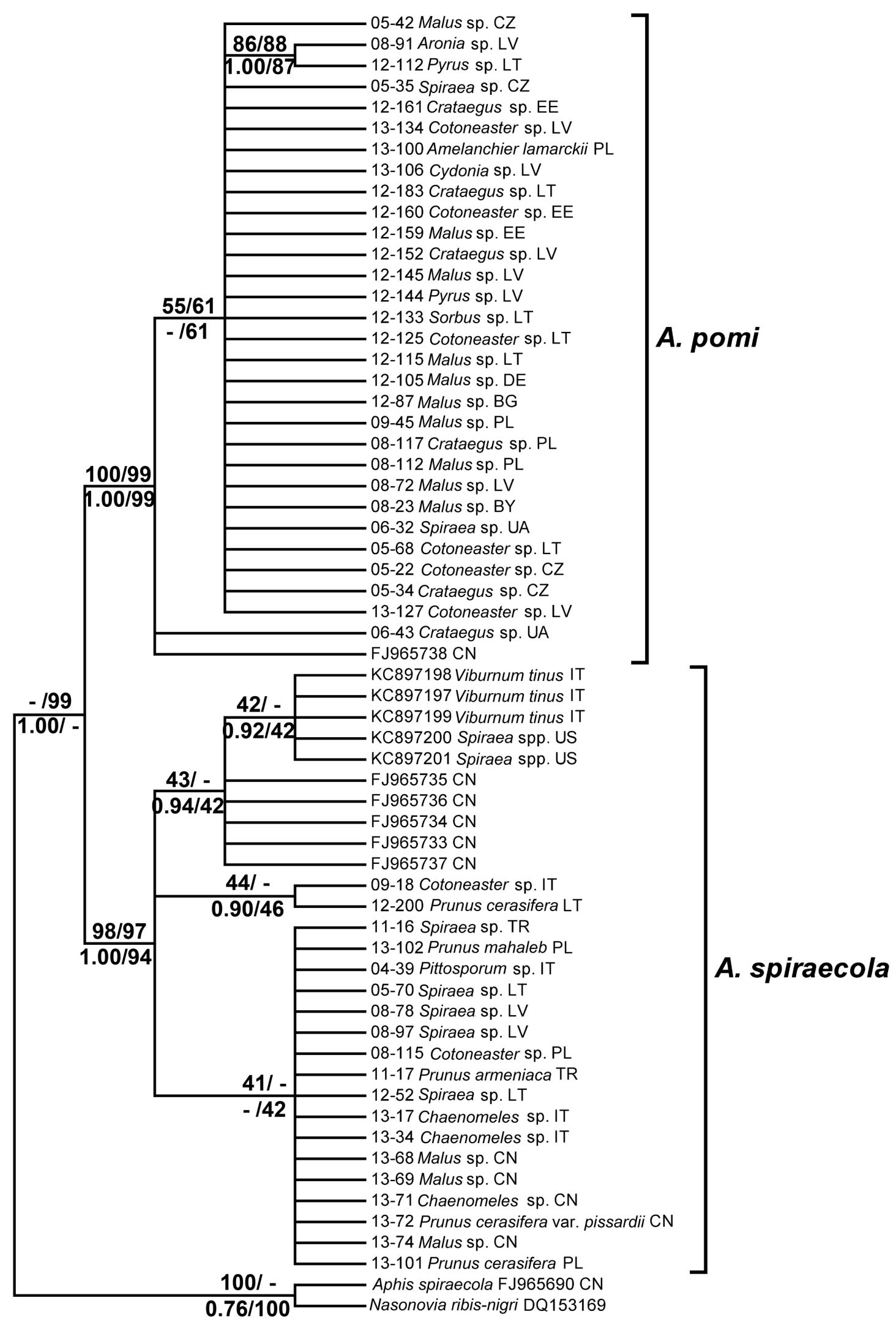

Fig. 2. Maximum Likelihood (ML) tree showing phylogenetic relationships among A. pomi and A. spiraecola based on partial sequences of mitochondrial COI (621 positions in final set). Numbers above branches indicate support of NJ (left, >40\%) and MP (right, $>40 \%$ ) based on bootstrap test with 1000 replicates, and numbers below branches indicate support of ML (right, > 40\%) bootstrap test with 1000 replicates and posterior probabilities of BI analysis (left, >0.50). Sample numbers are the same as in Tables $1-2$, together with the abbreviated symbol of the relevant country BG - Bulgaria, BY - Belarus, CN - China, CZ - Czech Republic, DE - Germany, EE - Estonia, IT - Italy, LV - Latvia, LT - Lithuania, PL - Poland, TR - Turkey, UA - Ukraine, US - United States of America. 


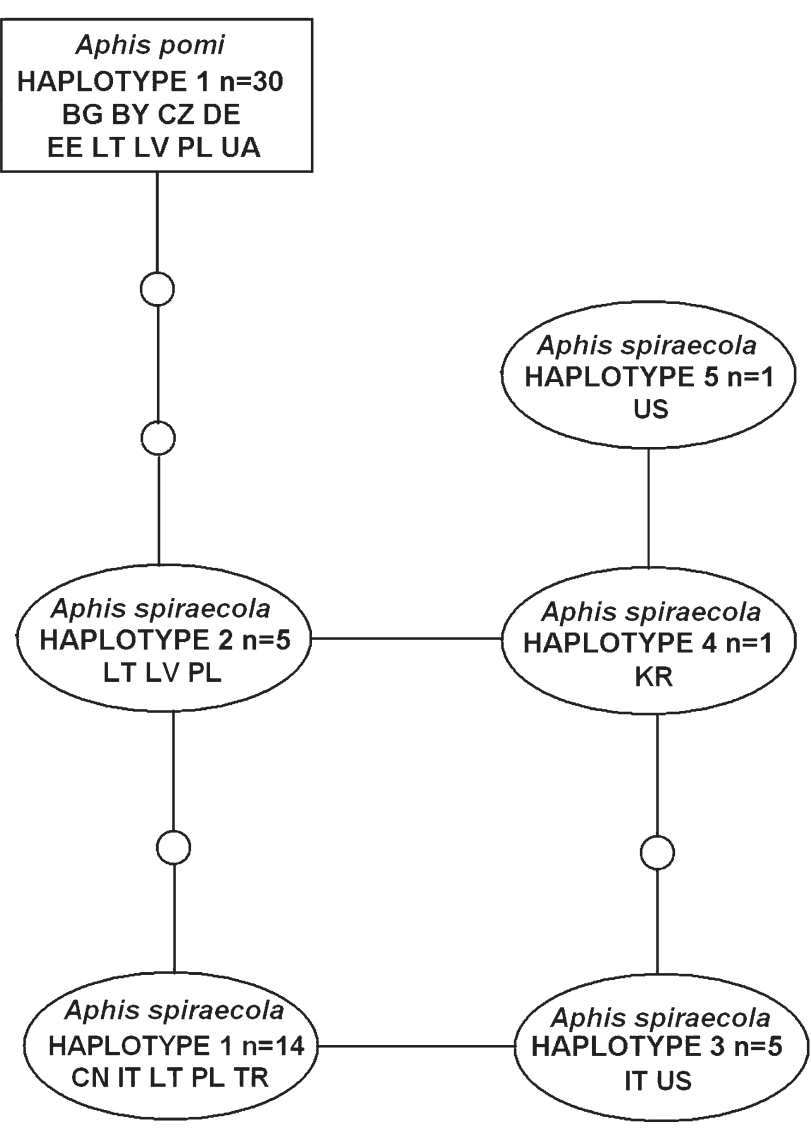

Fig. 3. Haplotype network for EF-1 $\alpha$ fragment (508 positions in final set, $95 \%$ connection limit, gaps treated as $5^{\text {th }}$ state) haplotypes of $A$. pomi and $A$. spiraecola. The haplotype with the highest outgroup probability is displayed as a square, while others are displayed as ovals. For sample information, see Tables 1-3. BG - Bulgaria, BY - Belarus, CN - China, CZ - Czech Republic, DE - Germany, EE - Estonia, IT - Italy, KR - Korea, LV - Latvia, LT - Lithuania, PL - Poland, TR - Turkey, UA - Ukraine, US United States of America.

the haplotype distribution of the spirea aphid partial EF-1 $\alpha$ sequences.

All partial EF-1 $\alpha$ sequences for the apple aphid $(\mathrm{n}=30)$ from 9 genera of pomoideous hosts were identical, thus, no correlation between haplotypes and host plant could be detected. Out of 26 partial EF-1 $\alpha$ sequences for the spirea aphid, host plant information was available for 20 and the commonest haplotype was associated with host plants of 6 genera: Prunus $(\mathrm{n}=4)$, Malus $(\mathrm{n}=3)$, Chaenomeles $(\mathrm{n}=$ $3)$, Cotoneaster $(\mathrm{n}=2)$, Spiraea $(\mathrm{n}=1)$ and Pittosporum $(\mathrm{n}$ =1). Haplotype No. 2 was collected predominantly from Spiraea $(\mathrm{n}=4)$, with just one sample from Prunus. Samples from Spiraea $(\mathrm{n}=3)$ and Viburnum $(\mathrm{n}=2)$ were of haplotype No. 3. Two remaining unique haplotypes were not unique in terms of their host plant associations, being collected from Spiraea (haplotype No. 4) and Malus (No. 5). As for COI haplotypes, our data do not indicate any host based background in the haplotype distribution of the spirea aphid partial EF-1 $\alpha$ sequences.

The maximum parsimony (MP) analysis of partial EF$1 \alpha$ sequences resulted in 1010 equally parsimonious trees (length $=56, \mathrm{CI}=0.80, \mathrm{RI}=0.98) . \mathrm{ML}$ tree $(\mathrm{T} 92$ model $)$ had a similar topology to the NJ (K2P distances) and BI $(\mathrm{F} 81+\mathrm{I}+\mathrm{G})$ analyses. NJ, MP and ML bootstrap values over $40 \%$ together with BI posterior probabilities over 0.50 are given at the respective nodes of the same tree in Fig. 4. The apple and spirea aphids form distinct clusters. The apple aphid clade is homogenous because the sequences are all identical. The clade of the spirea aphid appears more complex and includes three moderately supported branches, none of them with geographic or host plant specificity. Noticeably, spirea aphids from Italy and USA collected from Viburnum and Spiraea respectively, were grouped together both by their COI and EF-1 $\alpha$ partial sequences (COI haplotype No. 6 and EF-1 $\alpha$ haplotype No. 3, respectively, Tables 2-4, Figs 1-4). Of the 14 specimens of spirea aphid with identical sequence of EF-1 $\alpha$ (haplotype No. 1, Table 4) 12 also had identical COI sequences (haplotype No. 1, Table 3). Such congruence might indicate evolutionary specificity of certain lineages of spirea aphid.

Halbert \& Voegtlin (1992), followed by Blackman \& Eastop (2000), suggest three morphological characters can be used to discriminate between apterous viviparous females of apple and spirea aphids: numbers of marginal tubercles on abdominal tergites II-IV (present in apple aphid, absent in spirea aphid); numbers of caudal hairs (10-19 hairs

TABLE 4. EF-1 $\alpha$ haplotypes of Aphis pomi and Aphis spiraecola revealed by the haplotype network analysis. Sample numbers are the same as in Tables $1-2$.

\begin{tabular}{|c|c|c|c|}
\hline $\begin{array}{l}\text { Haplotype } \\
\text { no. }\end{array}$ & $\begin{array}{c}\text { No. of } \\
\text { sequences }\end{array}$ & $\begin{array}{l}\text { Length of haplotype } \\
\text { (bp) without gaps }\end{array}$ & Sequences belonging to haplotype \\
\hline \multicolumn{4}{|r|}{ Aphis pomi } \\
\hline 1 & 30 & 507 & $\begin{array}{c}05-22 ; 05-34 ; 05-35 ; 05-42 ; 05-68 ; 06-32 ; 06-43 ; 08-23 ; 08-72 ; 08-91 ; 08-112 ; 08-117 \\
09-45 ; 12-87 ; 12-105 ; 12-112 ; 12-115 ; 12-125 ; 12-133 ; 12-144 ; 12-145 ; 12-152 ; 12-159 ; \\
12-160 ; 12-161 ; 12-183 ; 13-100 ; 13-106 ; 13-127 ; 13-134\end{array}$ \\
\hline \multicolumn{4}{|r|}{ Aphis spiraecola } \\
\hline 1 & 14 & 507 & $\begin{array}{c}04-39 ; 09-18 ; 08-115 ; 11-16 ; 11-17 ; 12-200 ; 13-17 ; 13-34 ; 13-68 ; 13-69 ; 13-71 ; 13-72 ; \\
13-74 ; 13-102\end{array}$ \\
\hline 2 & 5 & 507 & $05-70 ; 08-78 ; 08-97 ; 12-52 ; 13-101$ \\
\hline 3 & 5 & 507 & KC897310; KC897309; KC897308; KC897307; KC897306 \\
\hline 4 & 1 & 507 & EU358925 \\
\hline 5 & 1 & 508 & AY219725 \\
\hline
\end{tabular}




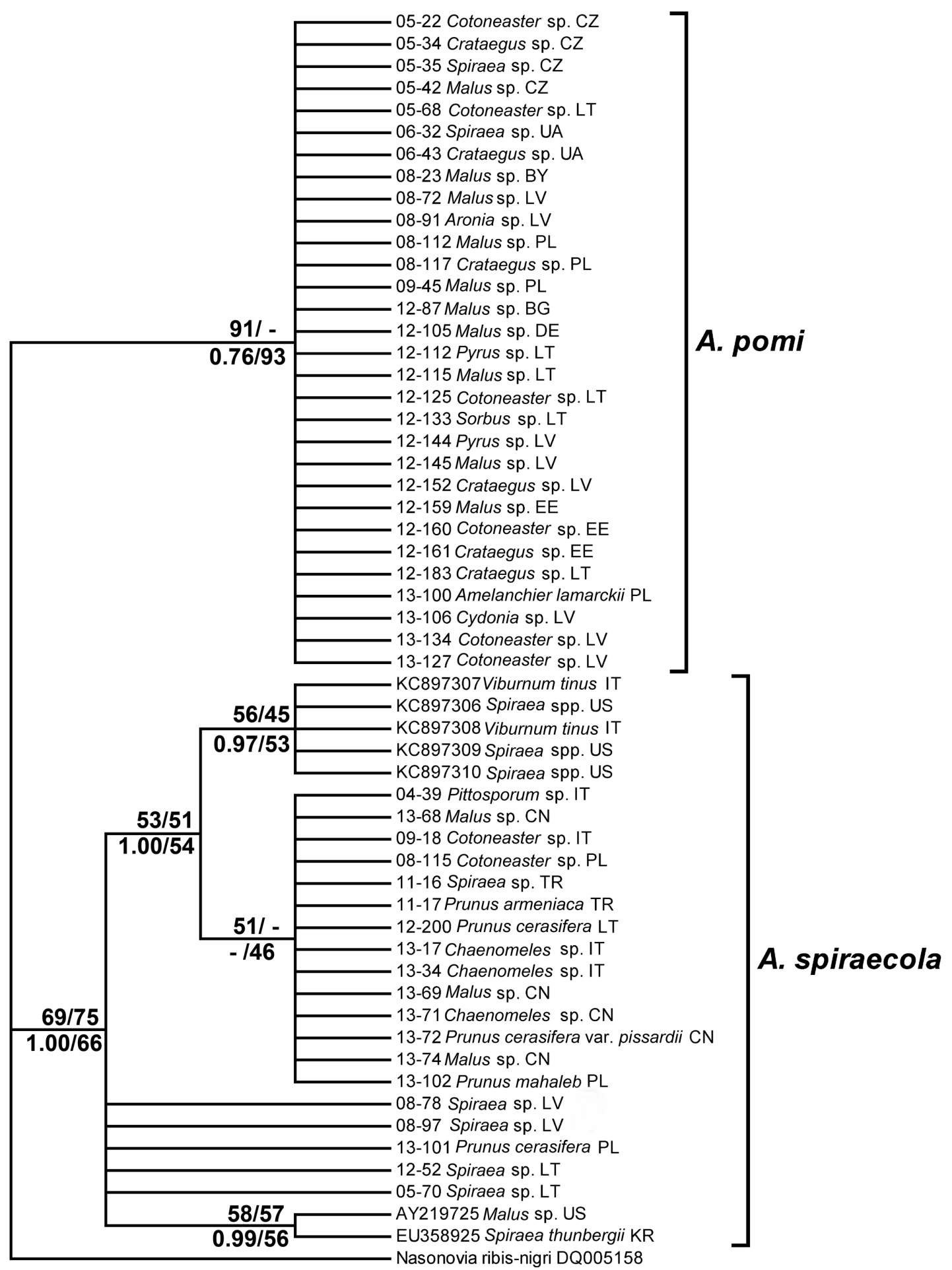

Fig. 4. Maximum Likelihood (ML) tree showing phylogenetic relationships among A. pomi and A. spiraecola based on partial sequences of nuclear EF-1 $\alpha$ (510 positions in final set). Numbers above branches indicate support of NJ (left, $>40 \%)$ and MP (right, $>40 \%$ ) based on bootstrap test with 1000 replicates, and numbers below branches indicate support of ML (right, $>40 \%$ ) bootstrap test with 1000 replicates and posterior probabilities of BI analysis (left, >0.50). Sample numbers are the same as in Tables 1-2, together with the abbreviated symbol of the relevant country BG - Bulgaria, BY - Belarus, CN - China, CZ - Czech Republic, DE - Germany, EE - Estonia, IT - Italy, KR - Korea, LV - Latvia, LT - Lithuania, PL - Poland, TR - Turkey, UA - Ukraine, US - United States of America.

in apple aphid, 7-15 in spirea aphid); length of ultimate rostral segment (exceeding $120 \mu \mathrm{m}$ in apple aphid, less than $120 \mu \mathrm{m}$ in spirea aphid). Of these three, the length of ultimate rostral segment appeared the most reliable when applied to our material: all individuals of apple aphid $(\mathrm{n}=$
143, Table 5) had ultimate rostral segment lengths greater than $120 \mu \mathrm{m}$ (mean 155.44; range 127-182). Of 94 individuals of spirea aphid collected in Europe, 86 (91.5\%) had an ultimate rostral segment length ranging from 76 to 120 $\mu \mathrm{m}$. Of 61 individuals of spirea aphid collected in China, 
TABLE 5. Summary statistics for the key morphological characters of apterae of Aphis pomi and A. spiraecola. For comparison the same data from Foottit et al. (2009) are given. URS - ultimate rostral segment length (all lengths in $\mu \mathrm{m}$ ), SIPHON - siphunculus length, CAUDA - length of cauda (apical part), MT2-4(5) - numbers of marginal tubercles on abdominal tergites II-IV(V), HCAUDA - numbers of caudal hairs, Siph/cauda - ratio of siphuncular length to caudal (apical part) length.

\begin{tabular}{|c|c|c|c|c|c|c|c|c|}
\hline \multirow{2}{*}{ Characters } & \multicolumn{4}{|c|}{ Aphis pomi } & \multicolumn{4}{|c|}{ Aphis spiraecola } \\
\hline & $n$ & Range & Mean & SD & $n$ & Range & Mean & SD \\
\hline \multicolumn{9}{|c|}{ Europe } \\
\hline URS & 143 & $127-182$ & 155.44 & 10.00 & 94 & $76-130$ & 104.98 & 14.00 \\
\hline SIPHON & 144 & $156-614$ & 417.30 & 80.00 & 94 & $94-470$ & 257.20 & 88.00 \\
\hline CAUDA & 143 & $78-179$ & 144.22 & 18.00 & 90 & $88-206$ & 141.19 & 21.95 \\
\hline MT2-4 & 144 & $2-6$ & 4.72 & 1.00 & 94 & $0-3$ & 0.33 & 0.66 \\
\hline HCAUDA & 144 & 8-23 & 14.77 & 3.00 & 92 & 7-19 & 12.19 & 2.83 \\
\hline Siph/cauda & 143 & $2.00-3.86$ & 2.88 & 0.32 & 90 & $0.67-2.77$ & 1.79 & 0.50 \\
\hline \multicolumn{9}{|c|}{ China } \\
\hline URS & & & & & 61 & $80-125$ & 100.40 & 13.14 \\
\hline SIPHON & & & & & 62 & $180-438$ & 284.29 & 48.11 \\
\hline CAUDA & & & & & 63 & $96-177$ & 129.35 & 20.40 \\
\hline MT2-4 & & & & & 63 & $0-2$ & 0.32 & 0.53 \\
\hline HCAUDA & & & & & 63 & $7-15$ & 10.21 & 1.76 \\
\hline Siph/cauda & & & & & 62 & $1.74-2.95$ & 2.21 & 0.29 \\
\hline \multicolumn{9}{|c|}{ Canada and USA (Foottit et al., 2009) } \\
\hline URS & 155 & $120-156$ & 139 & 7 & 54 & $94-123$ & 110 & 8 \\
\hline SIPHON & 155 & $167-562$ & 386 & 86 & 54 & $134-377$ & 266 & 58 \\
\hline CAUDA & 153 & 68-201 & 128 & 19 & 54 & $91-177$ & 141 & 21 \\
\hline MT2-5 & 154 & $1-7$ & 5.25 & 1.06 & 50 & $0-2$ & 0.24 & 0.65 \\
\hline HCAUDA & 155 & $10-21$ & 15.6 & 2.1 & 54 & $7-14$ & 10.4 & 1.8 \\
\hline Siph/cauda & & $>2.45$ & & & & $<2.45$ & & \\
\hline
\end{tabular}

$60(98.4 \%)$ had an ultimate rostral segment ranging from $80-120 \mu \mathrm{m}$. The numbers of marginal tubercles on abdominal tergites II-IV ranged from 2-6 in the apple aphid, compared to 0-3 in European collected spirea aphid (Table 5 ), which might result in the misidentification of $24.5 \%$ of the individuals of spirea aphid from Europe included in the present study. Of the 63 individuals of spirea aphid from China, 45 (71.4\%) lacked marginal tubercles on their abdominal tergites II-IV. Numbers of caudal hairs in both species showed much more overlap (Table 5). In addition to these three characters, Foottit et al. (2009) suggest the ratio of siphuncular length to caudal (apical part) length, with the threshold discriminating value being 2.45. In our case, this ratio ranged from 2.00 to 3.86 in the apple aphid, and for the spirea aphid it was $0.67-2.77$ and 1.74-2.95 for samples from Europe and China, respectively (Table 5).

\section{DISCUSSION}

Molecular markers are widely used to reveal cryptic insect species, including aphids (Rakauskas et al., 2011). Partial COI sequences used for DNA barcoding were analyzed for $A$. pomi $(\mathrm{n}=76)$ and $A$. spiraecola $(\mathrm{n}=56)$ by Foottit et al. (2009). The values of interspecific pairwise sample divergences were higher (mean $5.0 \%$, range $4.8-5.1 \%$ ) than those obtained for the COI fragments used in this study (mean 3.6\%, range 3.1-4.3\%). The majority of the spirea aphids (50 out of 56) from North America, Australia, Guam, Palau and Marshall Islands, also have identical COI barcode sequences (Foottit et al., 2009). The remaining individuals from New Zealand $(n=1)$, New
York $(\mathrm{n}=2)$ and British Columbia $(\mathrm{n}=3)$ differed from the most abundant COI haplotype by one to three base changes, giving a maximum pairwise within-species divergence of $0.6 \%$. In our study, maximum pairwise within-species divergence of the spirea aphid was $0.5 \%$ (average $0.2 \%$, range $0.0-0.5 \%$ ). This is in accordance with the conclusion of Foottit et al. (2009) that the variation in biological characteristics among populations of spirea aphid was greater than in those of apple aphid.

Analysis of COI barcode fragments indicate that sequences for the apple aphid collected in North America are identical (Foottit et al., 2009). In our study we recorded a greater diversity in COI fragments from European specimens of the apple aphid. Six haplotypes were detected in 30 samples. This might be because of the presumed Palaearctic origin of the apple aphid, which is reported to be a non-native species in the Nearctic, where it was first noted in North America in 1844 (Foottit et al., 2006). This fact could account for the homogeneity of apple aphid COI sequences from North American populations (Foottit et al., 2009). Unlike the partial COI sequences, our study indicates that partial sequences of the nuclear EF- $1 \alpha$ from European samples of the apple aphid are very homogeneous (1 haplotype, Table 4). Such homogeneity might be attributed to the isolated mode of reproduction of this species: gynoparae and males are apterous resulting in a high incidence of intraclonal inbreeding. Genetic consequences of such a reproductive system appear similar to those of anholocyclic populations resulting in a few predominant 
clones that appear to be considerably different from one another (Kanbe \& Akimoto, 2009).

In general, species level identification of apple and spirea aphids by means of COI and EF- $1 \alpha$ partial sequences coincided with that based on commonly used morphological characters (Halbert \& Voegtlin, 1992; Blackman \& Eastop, 2000; Foottit et al., 2009). However, none of the above mentioned morphological characters (Table 5) on their own can ensure a $100 \%$ correct discrimination between apple and spirea aphids. All four characters should be used to determine the identity of series of individual aphids in each sample. The situation might be even more complicated due to the presence of mixed colonies of both species. For example, apterous viviparous females $(\mathrm{n}=$ 5) collected from Cotoneaster in Lublin, Poland (sample 08-115) had clear morphological characters typical of the apple aphid: ultimate rostral segment length 148-156 $\mu \mathrm{m}$; numbers of marginal tubercles on abdominal tergites 4-6; ratio of siphuncular length to caudal length 2.40-2.80. For DNA extraction one winged individual aphid was used and its sequence grouped together with those of the spirea aphid. When the morphology of the voucher specimen was checked, it resembled the spirea aphid. This case demonstrates that mixed colonies might also complicate identification by means of DNA sequences, because several individuals per colony should be subject to DNA analysis.

ACKNOWLEDGEMENTS. This research was funded by a grant (No. LEK-04/2012) from the Research Council of Lithuania. Kind assistance of S. Barbagallo and G. Cocuzza (Catania, Sicily), S. Buga (Minsk, Belarus), V. Zhuravlev (Kyiv, Ukraine) V. Spungéis (Riga, Latvia), M. Badini (Bagnolo Mella, Italy), A.A. Işıkber and M.M. Aslan, (Kahramanmaraş, Turkey) during field sampling in their respective countries cannot be overestimated. We wish to thank A.S. Jensen for language correction. Our appreciation is also due to A. Zaremba (Vilnius, Lithuania) for the preparation of microscope slides.

\section{REFERENCES}

BAKer A.C. \& TuRner W.F. 1916: Morphology and biology of the green apple aphis. - J. Agr. Res. 5: 955-994.

Barbagallo S., Cravedi P., Pasqualini E., Patti I. \& Stroyan H.L.G. 1997: Aphids of the Principal Fruit-Bearing Crops. Grafiche Leardini, Verona, $123 \mathrm{pp}$.

Blackman R.L. \& Eastop V.F. 2000: Aphids on the World's Crops: An Identification and Information Guide. John Wiley and Sons, Chichester, $414 \mathrm{pp}$.

Brown M.W. 2011: Importance of early arrival of adult Harmonia axyridis for control of Aphis spiraecola on apple. - Biocontrol 56: 65-69.

Brown M.W., Hogmire H.W. \& Schmitt J.J. 1995: Competitive displacement of apple aphid by spirea aphid (Homoptera: Aphididae) on apple as mediated by human activities. - Environ. Entomol. 24: 1581-1591.

Brown M.W. \& Mathews C.R. 2008: Conservation biological control of spirea aphid, Aphis spiraecola (Hemiptera: Aphididae) on apple by providing natural alternative food resources. - Eur. J. Entomol. 105: 537-540.

Caglayan K., Serce C.U., Gazel M., Kaya K., Cengiz F.C., Vidal E. \& CAMBra M. 2013: Evaluation of the susceptibility of different Prunus rootstocks to natural infection of Plum pox virusT. - J. Plant Pathol. 95: 579-586.
CAo J., Li J., Niu J., Liu X. \& Zhang Q. 2012: Population structure of Aphis spiraecola (Hemiptera: Aphididae) on pear trees in China identified using microsatellites. - J. Econ. Entomol. 105: 583-591.

Clement M., Posada D. \& Crandall K.A. 2000: TCS: a computer program to estimate gene genealogies. - Mol. Ecol. 9: $1657-1659$.

Davletshina A.G. 1963: Aphids of the Genus Aphis L. of the Uzbekistan Fauna. Nauka, Tashkent, 135 pp. [in Russian].

Foottit R.G., Halbert S.E., Miller G.L., Maw H.E.L. \& RusSELL L.M. 2006: Adventive aphids (Hemiptera: Aphididae) of America north of Mexico. — Proc. Entomol. Soc. Wash. 108: 583-610.

Foottit R.G., Lowery D.T., Maw H.E.L., Smirle M.J. \& Lushai G. 2009: Identification, distribution, and molecular characterization of the apple aphids Aphis pomi and Aphis spiraecola (Hemiptera: Aphididae: Aphidinae). - Can. Entomol. 141: 478-495.

Frechette B., Cormier D., Chouinard G., Vanoosthuyse F. \& LuCAs E. 2008: Apple aphid, Aphis spp. (Hemiptera: Aphididae), and predator populations in an apple orchard at the nonbearing stage: The impact of ground cover and cultivar. - Eur. J. Entomol. 105: 521-529.

GRASSWITZ T.R. \& BuRTS E.C. 1995: Effect of native natural enemies and augmentative releases of Chrysoperla rufilabris Burmeister and Aphidoletes aphidimyza (Rondani) on the population dynamics of the green apple aphid, Aphis pomi De Geer. - Int. J. Pest Manag. 41: 176-183.

Halbert S.E. \& Voegtlin D.J.1992: Morphological differentiation between Aphis spiraecola and Aphis pomi (Homoptera, Aphididae). - Great Lakes Entomol. 25: 1-8.

HaLl T.A. 1999: BioEdit: a user-friendly biological sequence alignment editor and analysis program for Windows 95/98/NT. — Nucl. Acid. Symp. 41: 95-98.

HeIE O.E. 1986: The Aphidoidea (Hemiptera) of Fennoscandia and Denmark. III. Family Aphididae: Subfamily Pterocommatinae and Tribe Aphidini of Subfamily Aphidinae. Fauna Entomologica Scandinavica 17. E.J. Brill/Scandinavian Science Press, Leiden, Copenhagen, 316 pp.

Hogmire H.W., Brown M.W., Schmitt J.J. \& Winfield T.M. 1992: Population development and insecticide susceptibility of apple aphid and spirea aphid (Homoptera, Aphididae) on apple. $-J$. Entomol. Sci. 27: 113-119.

Holman J. 2009: Host Plant Catalog of Aphids: Palaearctic Region. Springer, New York, 1140 pp.

JAŚKIEWICZ B. \& KоT I. 2007: The population dynamics of Aphis pomi De Geer on Cotoneaster divaricatus Rehd. et Wils. Aphids and other Homopterous Insects 13: 121-127.

Kaakeh W., Pfeiffer D.G. \& Marini R.P. 1993: Effect of Aphis spiraecola and A. pomi (Homoptera, Aphididae) on the growth of young apple trees. - Crop Prot. 12: 141-147.

KanBe T. \& Акімото S.I. 2009: Allelic and genotypic diversity in long-term asexual populations of the pea aphid, Acyrthosiphon pisum in comparison with sexual populations. - Mol. Ecol. 18: 801-816.

KARCZEWSKA M. 1965: Badania nad biologią mszyc (Aphididae) występujących na jabloni. [Studies on the biology of aphids (Aphididae) occurring on apple trees]. - Pol. Pis. Entomol. (B) 16: 245-296.

Kim H. \& LeE S. 2008: A molecular phylogeny of the tribe Aphidini (Insecta: Hemiptera: Aphididae) based on the mitochondrial tRNA/COII, $12 \mathrm{~S} / 16 \mathrm{~S}$ and the nuclear EF1alpha genes. - Syst. Entomol. 33: 711-721.

KomAZAKI S. 1990: Variation in the hatch timing of the overwintering egg among populations of Aphis spiraecola Patch (Ho- 
moptera, Aphididae) collected from different host plants and localities in Japan. - Appl. Entomol. Zool. 25: 27-34.

LABANOWSKI G. 2008: Aphids (Hemiptera, Aphidoidea) on garden perennial plants. - Aphids and other Homopterous Insects 14 $21-37$.

Lagos D.M., Voegtlin D.J., Coeur D'acier A. \& Giordano R. 2014: Aphis (Hemiptera: Aphididae) species groups found in the Midwestern United States and their contribution to the phylogenetic knowledge of the genus. - Insect Sci. 21: 374-391.

Lowery D.T., Smirle M.J., Foottit R.G. \& Beers E.H. 2006: Susceptibilities of apple aphid and spirea aphid collected from apple in the Pacific Northwest to selected insecticides. - J. Econ. Entomol. 99: 1369-1374.

Lushai G., Foottit R., Maw E. \& Barette R. 2004: Genetic variation in the green apple aphid, Aphis pomi De Geer (Aphididae, Homoptera) detected using microsatellite DNA flanking sequences. In Simon J.C., Dedryver C.A., Rispe C. \& Hullé M. (eds): Aphids in a New Millennium. INRA, Paris, pp. 245-251.

NaAum A.M., Foottit R.G., Maw H.E.L. \& Hanner R. 2012: Differentiation between Aphis pomi and Aphis spiraecola using multiplex real-time PCR based on DNA barcode sequences. J. Appl. Entomol. 136: 704-710.

Nieto Nafría J.M., Andreev A.V., Binazzi A., Mier Durante M.P., Pérez Hidalgo N., Rakauskas R. \& Stekolshchikov A.V. 2010: Aphidoidea. Fauna Europaea. Version 2.2. http://www. faunaeur.org

Palmer M.A. 1952: Aphids of the Rocky Mountain Region. Hirschfeld Press, Denver, 452 pp.

PAтCH E.M. 1923: The summer food plants of the green apple aphid. - Maine AES Bull. 313: 45-68.

Patch E.M. 1929: The apple aphid and the citrus aphid: Aphis pomi DeGeer and A. spiraecola Patch. - J. Econ. Entomol. 22: 698.

Posada D. 2008: jModelTest: Phylogenetic model averaging. Mol. Biol. Evol. 25: 1253-1256.

Rakauskas R. \& Buga S. 2010: Contribution to the knowledge of the aphid (Hemiptera, Sternorrhyncha: Aphidoidea) fauna of the Gorodok Highland, Belarus. - Acta Zool. Lituan. 20: 205-224.

RAKAUSKAS R.P. \& RUPAIS A.A. 1983: Biology of the green apple aphid in Lithuania. - Acta Entomol. Lituan. 6: 20-30 [in Russian].

RAKAuSKas R., TurČINAVIČIENĖ J. \& BAŠILOVA J. 2011: How many species are there in the subgenus Bursaphis (Hemiptera: Sternorrhyncha: Aphididae)? COI evidence. - Eur. J. Entomol. 108: 469-479.

Ronquist F. \& HuelsenBeck J.P. 2003: MRBAYES 3: Bayesian phylogenetic inference under mixed models. - Bioinformatics 19: $1572-1574$.
Singh R.S. \& RHOMBERG L. 1984: Allozyme variation, population structure, and sibling species in Aphis pomi. - Can. J. Genet. Cytol. 26: 364-373.

Smirle M.J., Zurowski C.L., Lowery D.T. \& Foottit R.G. 2010: Relationship of insecticide tolerance to esterase enzyme activity in Aphis pomi and Aphis spiraecola (Hemiptera: Aphididae). - J. Econ. Entomol. 103: 374-378.

Stoeckli S., Mody K. \& Dorn S. 2008: Aphis pomi (Hemiptera: Aphididae) population development, shoot characteristics, and antibiosis resistance in different apple genotypes. - J. Econ. Entomol. 101: 1341-1348.

Stroyan H.L.G. 1985: Aphids - Aphidinae (Macrosiphini). In: Handbooks for the Identification of British Insects. Royal Entomological Society, London, $414 \mathrm{pp}$.

Tamura K., Peterson D., Peterson N., Stecher G., Nei M. \& KuMAR S. 2011: MEGA5: Molecular evolutionary genetics analysis using maximum likelihood, evolutionary distance, and maximum parsimony methods. - Mol. Biol. Evol. 28: 2731-2739.

TSAI J.H. \& WANG J.J. 2001: Effects of host plants on biology and life table parameters of Aphis spiraecola (Homoptera: Aphididae). - Environ. Entomol. 30: 44-50.

Turčinavičiené J., Pedersen B.V. \& Rakauskas R. 2006: Phylogenetic relationships in the "grossulariae" species group of the genus Aphis (Hemiptera: Sternorrhyncha: Aphididae): Molecular evidence. - Eur. J. Entomol. 103: 597-604.

von Dohlen C.D. \& Teulon D.A.J. 2003: Phylogeny and historical biogeography of New Zealand indigenous Aphidini aphids (Hemiptera, Aphididae): An hypothesis. - Ann. Entomol. Soc. Am. 96: 107-116.

von Dohlen C.D., Rowe C.A. \& HeIE O.E. 2006: A test of morphological hypotheses for tribal and subtribal relationships of Aphidinae (Insecta: Hemiptera: Aphididae) using DNA sequences. - Mol. Phylogenet. Evol. 38: 316-329.

WANG J.F., JiANG L.Y. \& QIAO G.X. 2011: Use of a mitochondrial $\mathrm{COI}$ sequence to identify species of the subtribe Aphidina (Hemiptera, Aphididae). - ZooKeys 122: 1-17.

Westigard P.H. \& Madsen H.F. 1964: Oviposition and egg dispersion of apple aphid. - J. Econ. Entomol. 57: 597-600.

Wieczorek K., Bartosz J., PŁachno B.J. \& Swiątek P. 2011: Comparative morphology of the male genitalia of Aphididae (Insecta, Hemiptera). Part 1. - Zoomorphology 130: 289-303. Yovkova M., Petrović-Obradović O., Tasheva-Terzieva E. \& Pencheva A. 2013: Aphids (Hemiptera, Aphididae) on ornamental plants in greenhouses in Bulgaria. - ZooKeys 319: 347-361.

Received September 22, 2014; revised and accepted January 7, 2015 Prepublished online February 16, 2015 